\title{
A Review of Energy Security Index Dimensions and Organization
}

\author{
Zhen $\mathrm{Yu}^{1}$, Jinpo $\mathrm{Li}^{1}$, Ge Yang ${ }^{1}$ \\ 1 Institute for the U.S. and Canadian Economies, Wuhan University, China \\ Keywords: energy security index, dimensions, organization \\ https://doi.org/10.46557/001c.28914
}

\section{Energy RESEARCH LETTERS}

Vol. 3, Issue 1, 2022

\begin{abstract}
This note reviews the indexes used in academic studies and official reports to quantify energy security levels. With the enrichment of energy security connotation, the dimension and organization of such indexes have undergone changes, such as the index becoming much more complex and the indicators considering more environmental, technological, and social issues. Though official reports have preferred projections more than journal papers, projections are still not a main focus of the energy security index.
\end{abstract}

\section{Introduction}

Regarded as the lifeblood of economic development, energy is an important guarantee for national economic development and daily life. According to the World Energy Balances by the International Energy Agency, industrial, transportation, and residential activities account for nearly 80 percent of the final energy consumption. In other words, modern life is entirely based on energy. In the face of the COVID-19 pandemic, it is particularly important to revisit the issue of energy security. International trade has been restricted, and the volume of trade has fallen sharply. Transportation interruptions and shrinking storage space has put the supply security of energy-importing countries at risk. Besides, the global commodity market has witnessed large shocks, and commodity prices have fluctuated greatly. Thus, energy-importing countries are facing risks in the international market and the risk of supply chain disruption. For them, ensuring an adequate, reliable, and environmentally friendly energy supply has become the primary goal and challenge.

Energy security is a multifaceted issue involving national security and foreign strategy. It is also a global issue related to international energy supply and energy geopolitics. Globally, the distributions of energy production and energy consumption do not have similar patterns. Therefore, it is impossible for most countries to leave international cooperation and obtain energy security guarantees. Since the first oil crisis in the 1970s, the issue of energy security has been recognized worldwide. The conflicts in the Middle East have led to global oil shortages and soaring oil prices, triggering the most serious global economic crisis since World War II. Since then, the concept of energy security centered on stabilizing the supply and price of crude oil has been formally put forward, and Western countries have formulated energy policies focused on energy supply security.

Under certain conditions, the possibility of global shortterm oil supply interruption or oil crisis still exists. With the accelerated process of globalization and concerns about environmental issues at the end of the 20th century, the issue of energy security has taken ecological environmental and sustainable development strategies into account. Energy security is not only about energy supply, but also comprehensive risks, including energy transportation and energy use. Moreover, global warming has prompted the international community to re-examine the issue of sustainable development and pay more attention to the issue of climate change caused by energy use. The definition of energy security has been expanded to ensure adequate and reliable energy supply by increasing economic competitiveness and reducing environmental degradation.

To cope with the newly emerged risks, we need an appropriate index to evaluate the energy security level of each country. A significant amount of theoretical work has been conducted to investigate and quantify the energy security level in different countries and regions. These apply various dimensions and construction methodologies. Therefore, this note aims to briefly review the recent research.

\section{Literature overview}

In the discussion of energy security, most of the literature tries to use a general methodology to formalize its definition and clarify the questions. The use of quantitative methods has become mainstream in energy security studies, especially in cross-country comparisons and long-term research. We choose eight research studies in energy security as an example to give a brief overview of the recent trend in this area (see Table 1). 
Table 1. List of typical energy security index studies.

\begin{tabular}{|c|c|c|c|c|c|c|c|}
\hline & $\begin{array}{c}\text { Typical } \\
\text { publication }\end{array}$ & $\begin{array}{l}\text { Publication } \\
\text { type }\end{array}$ & $\begin{array}{l}\text { Geographical } \\
\text { coverage }\end{array}$ & $\begin{array}{l}\text { Number } \\
\text { of } \\
\text { indicators }\end{array}$ & projections & Dimensions & $\begin{array}{l}\text { Themes in energy security } \\
\text { definition }\end{array}$ \\
\hline 1 & $\begin{array}{l}\text { Le Coq \& } \\
\text { Paltseva } \\
\text { (2009) }\end{array}$ & $\begin{array}{l}\text { Journal } \\
\text { paper }\end{array}$ & EU & 2 & No & Oil; gas; coal & $\begin{array}{l}\text { Energy availability, } \\
\text { infrastructure, energy prices }\end{array}$ \\
\hline 2 & $\begin{array}{l}\text { Lefèvre } \\
(2007)\end{array}$ & $\begin{array}{l}\text { Official } \\
\text { report }\end{array}$ & $\begin{array}{l}\text { OECD } \\
\text { countries }\end{array}$ & 2 & Yes & Energy price; physical availability & $\begin{array}{l}\text { Energy availability, energy } \\
\text { prices }\end{array}$ \\
\hline 3 & $\begin{array}{l}\text { Sovacool } \\
(2011)\end{array}$ & $\begin{array}{l}\text { Journal } \\
\text { paper }\end{array}$ & $\begin{array}{l}\text { Asia-pacific } \\
\text { countries }\end{array}$ & 200 & No & $\begin{array}{l}\text { Availability; dependency; diversification; innovation; investment; } \\
\text { trade; production, price stability; affordability; governance; access; } \\
\text { reliability; literacy; resilience; pollution; efficiency; greenhouse gas } \\
\text { emissions }\end{array}$ & $\begin{array}{l}\text { Energy availability, energy } \\
\text { prices, environment, efficiency. }\end{array}$ \\
\hline 4 & $\begin{array}{l}\text { Vivoda } \\
\text { (2010) }\end{array}$ & $\begin{array}{l}\text { Journal } \\
\text { paper }\end{array}$ & $\begin{array}{l}\text { Asia-pacific } \\
\text { countries }\end{array}$ & 44 & No & $\begin{array}{l}\text { Energy supply; demand management; efficiency; economic, } \\
\text { environmental; human security; military security; domestic socio- } \\
\text { cultural-political; technological; international policy }\end{array}$ & $\begin{array}{l}\text { Energy availability, } \\
\text { infrastructure, energy price, } \\
\text { societal effects, environment, } \\
\text { governance and efficiency }\end{array}$ \\
\hline 5 & $\begin{array}{l}\text { Zhang et al. } \\
\text { (2013) }\end{array}$ & $\begin{array}{l}\text { Journal } \\
\text { paper }\end{array}$ & China & 8 & No & $\begin{array}{l}\text { External dependence; supply stability; trade economy; } \\
\text { transportation safety }\end{array}$ & $\begin{array}{l}\text { Energy availability, energy } \\
\text { prices }\end{array}$ \\
\hline 6 & $\begin{array}{l}\text { Boccauthor } \\
\text { \& Hanna } \\
(2016)\end{array}$ & $\begin{array}{l}\text { Official } \\
\text { report }\end{array}$ & Global & 18 & No & $\begin{array}{l}\text { Economic growth and development; environmental sustainability; } \\
\text { energy access and security }\end{array}$ & $\begin{array}{l}\text { Energy availability, } \\
\text { infrastructure, energy price, } \\
\text { environment, efficiency }\end{array}$ \\
\hline 7 & $\begin{array}{l}\text { World } \\
\text { Energy } \\
\text { Council } \\
\text { (2018) }\end{array}$ & $\begin{array}{l}\text { Official } \\
\text { report }\end{array}$ & Global & 35 & No & Energy security; energy equity; environmental sustainability & $\begin{array}{l}\text { Energy availability, } \\
\text { infrastructure, energy price, } \\
\text { environment }\end{array}$ \\
\hline \multirow[t]{2}{*}{8} & $\begin{array}{l}\text { Song et al. } \\
\text { (2019) }\end{array}$ & $\begin{array}{l}\text { Journal } \\
\text { paper }\end{array}$ & China & 18 & No & Energy supply; environmental; economic-technical & $\begin{array}{l}\text { Energy availability, } \\
\text { infrastructure, energy price, } \\
\text { environment, governance and } \\
\text { efficiency }\end{array}$ \\
\hline & $\begin{array}{l}\text { lyke et al. } \\
\text { (2021) }\end{array}$ & Journal & US & 10 & No & Energy supply, demand, development & $\begin{array}{l}\text { Energy availability, } \\
\text { affordability, accessibility, } \\
\text { acceptability, and } \\
\text { developability }\end{array}$ \\
\hline
\end{tabular}


After reading these studies, we collected their main index organization information. Specifically, we consider the studies' publication type, geographical coverage, number of indicators, whether they use their own index in the projections, the main dimensions of the index, and the definitions of the themes.

The publication type mainly considers the impact of the different research types. Journal papers mainly focus on academic problems whose analysis requires an index, whereas official reports have the generally goal of regional or global policy making. Therefore, the publication type reveals the different preferences in generating an energy security index.

Geographical coverage shows the energy security indexes generated by researchers for different regions, indicating the spatial ranges to which those indexes can be applied. Generally, there are three types of geographical coverage: a) global coverage, which includes most countries of the world; b) regional coverage, focusing on particular regions, for example, Asian countries, the European Union, or countries in the Organisation for Economic Co-operation and Development; and c) that of specific countries, analyzing only a single country's energy security situation. Different regions would lead to different analysis foci.

The number of indicators mainly focuses on the complexity of the index. The more indicators an index uses, the greater the difficulty in collecting the data and conducting comparisons. A simple indicator generally focuses on a narrow aspect of energy security, while compound indicators cover more relative considerations in terms of analysis.

Whether studies use their own index in projections mainly considers their use of the index. Energy security focuses on recent situations and general trends, which means that it only has an effect under very strict conditions in the future. Such indexes cannot capture unexpected events.

The main dimension of the index comprises the main part of analysis. Since the meaning of energy security has changed over the years, energy security indexes also now contain more dimensions in terms of their organization. These dimensions could shed light on the main concerns in the index organization.

Last are the themes of the definition of energy security. Because of the complexity of energy security, its definition varies across studies. We follow the research of Ang et al. (2015) and focus on seven aspects of themes: energy availability, infrastructure, energy prices, societal effects, the environment, governance, and energy efficiency. Energy availability focuses on the energy supply and transport route diversity. Infrastructure focuses on the stabilization of energy supply. Energy prices mainly consider price volatility, since most of the energy trade uses U.S. dollars and largely depends on the global energy market. Societal effects relate to living standards. The environment represents pollution and carbon emission problems. Governance focuses on governmental policymaking, the provision of information, and diplomacy. Energy efficiency is linked to technology, because high efficiency can reduce energy requirements and thus relatively enhance energy security at certain available energy levels.

\section{Discussion}

Generally, the energy security index has become much more complex in recent studies. We can see in recent studies 6 to 8 that the number of indicators is around 20-30, which is a relatively plausible number. In the early studies 1 and 2 , the indicator is simply relative to the energy supply and prices, the most direct aspects of energy security, namely, whether the energy, including oil, gas, and coal, are accessible and whether the energy price is stable and foreseeable. Although these two considerations are the most basic aspect of energy security, they are not sufficient to cover the problems of energy security. However, research such as studies 3 and 4 use quite a few indicators in their measurements. Study 3, with 200 indicators in the index, could be an extreme example of index organization. More indicators could cover more relevant impact factors in energy security. Although studies 3 and 4 consider more dimensions, too many indicators would require more work in terms of data collection. In addition, such complexity would make it harder to conduct cross-country analyses, because there is no guarantee the same number of indicators can be found for each country.

Another feature is relative to the indicator. Recent energy security studies consider larger numbers of relative factors, and environmental problems thus play an important role. Carbon emissions and clean energy usage are two main concerns. If traditional fossil energy is not sustainable and causes global warming, energy security should consider the problem of its replacement and the extreme event shock. A great example is the growing solar power industry and the COVID-19 pandemic shock to the global energy market in 2020.

Beside the environment, technological and social issues have also become an essential part of energy security index organization. Technology is mainly linked to the environment and energy efficiency. New technological processes can lead to greater energy supply and create new energy demand. The shale oil industry is a good example of new technology creating new energy supply. New technology also creates new energy types, such as solar power and hydropower. So-called green energy can become more controllable for countries, allowing them to stop having to depend on energy imports from energy-exporting countries. Such a trend would reshape the future energy market and change the focus of energy security. Therefore, the indexes in studies 3, 4, and 6 to 8 all consider technological issues.

Social issues mainly involve the relative influence of energy use. For example, the index in study 6 considers the economic growth dimension. In study 4 , the index also considers human and military security. All those considerations could be categorized as social issues. This trend in recent analysis is mainly because the scope of energy security has gradually grown beyond a simple energy supply and demand problem. Energy plays a fundamental role in the economy, and hence energy security cannot be excluded from political analysis and debates. Governments aim to protect energy security to keep the economy stable and growth steady. Therefore, social issues must be considered in organizing the energy security index.

As for the index effectiveness problem, we can see that 
most journal papers do not use their own index in projections. It is plausible that journal papers do not focus on predictions, partly because of the technical difficulties and partly because of the unpredictable event shocks. Only the International Energy Agency's report contains a projection section. However, this kind of projection does not concern detailed predictions of future events, but is more similar to macro trend projections. Overall, the projection is not the main focus of the energy security index, whose function is to provide a brief picture of energy vulnerability in different sectors and to guide the researcher and policymaker in delving deeper in future studies.

\section{Conclusion}

The energy security problem is an old but important issue in energy economics. We provide a brief overview of the energy security index's dimensions and organization in recent research. We focus on the main topic covered by the index and how recent research treats real-world issues in the index organization. Energy security indexes have clearly become more complex, and the focus broader, from simple energy market issues to environmental, technological, and social issues. Journal papers do not provide as many projections as official reports do, but the latter are mainly used to predict trends, where the aim is still to provide guidance for future research and policymaking. 


\section{REFERENCES}

Ang, B. W., Choong, W. L., \& Ng, T. S. (2015). Energy security: Definitions, dimensions and indexes. Renewable and Sustainable Energy Reviews, 42, 1077-1093.

Boccauthor, R., \& Hanna, A. (2016). Global Energy Architecture Performance Index Report. World Economic Forum.

Iyke, B. N., Tran, V. T., \& Narayan, P. K. (2021). Can energy security predict energy stock returns? Energy Economics, 94, 105052. https://doi.org/10.1016/j.enec o.2020.105052

Le Coq, C., \& Paltseva, E. (2009). Measuring the Security of External Energy Supply in the European Union. Energy Policy, 37(11), 4474-4481. https://doi.org/10.1 016/j.enpol.2009.05.069

Lefèvre, N. (2007). Energy Security and Climate Policy: Assessing Interactions. IEA/OECD.
Song, Y., Zhang, M., \& Sun, R. (2019). Using a new aggregated indicator to evaluate China's energy security. Energy Policy, 132, 167-174. https://doi.org/1 $\underline{0.1016 / j . e n p o l .2019 .05 .036}$

Sovacool, B. K. (2011). Evaluating Energy Security in the Asia Pacific: Towards a More Comprehensive Approach. Energy Policy, 39(11), 7472-7479. https://d oi.org/10.1016/j.enpol.2010.10.008

Vivoda, V. (2010). Evaluating Energy Security in the Asia-Pacific Region: A Novel Methodological Approach. Energy Policy, 38(9), 5258-5263. https://do i.org/10.1016/i.enpol.2010.05.028

World Energy Council. (2018). World Energy Trilemma Index.

Zhang, H.-Y., Ji, Q., \& Fan, Y. (2013). An Evaluation Framework for Oil Import Security Based on the Supply Chain with a Case Study Focused on China. Energy Economics, 38, 87-95. https://doi.org/10.1016/ j.eneco.2013.03.014 